\title{
The impact of the Tourism Village on the socio- economic conditions of the local agrarian community in Pujon Kidul Village, Pujon District, Batu City, Indonesia
}

\author{
Setyo Parsudi, Sri Widayanti, Muhammad Fachrizal Amirrahman, Sri Tjondro Winarno*, Laksmi Budiana \\ Agribusiness Department, Agriculture Faculty, Universitas Pembangunan Nasional “Veteran” Jawa Timur, Indonesia \\ Correspondent Author* \\ DOI: https://dx.doi.org/10.47772/IJRISS.2021.5330
}

\begin{abstract}
The purpose of this study was to determine the impact of the tourism village on the socio-economic conditions of the local agrarian community in Pujon Kidul Village, Pujon District, Batu City. The location of this study was determined purposively, the sample used was 100 people with details of 30 employees working in tourist attractions, 30 people from the surrounding community, and 40 people from tourists. The types of data used in this study are primary data and secondary data. The results showed that the economic impact was increasing family income, increasing the standard of living of the community, reducing the number of unemployed. The social impact increases public confidence in tourism objects, improves the performance of social institutions, improves work ethic, maintains security and improves family relations.
\end{abstract}

Keywords: Tourism, Social, Economy, Impact, Agrarian Community

\section{INTRODUCTION}

$\mathrm{T}$ he development of natural resources into agro-tourism is one way to increase income and explore the economic potential of an area, especially for small farmers and rural communities. The attraction offered by the existence of agrotourism is expected so that tourists can enjoy the beauty of nature and can be directly involved in agricultural activities. Agro-tourism is a tourism activity in agricultural areas with the aim of recreation and increasing knowledge. Agriculture in a broad sense includes smallholder agriculture, plantations, animal husbandry and fisheries (Sudiasa, 2005).

Batu City as one of the tourism development areas located in East Java Province. Located in an area of 871 meters above sea level, surrounded by hills with cool air and has abundant and varied agricultural products, it is an added value that has the potential to be managed by the government to become an agricultural-based tourism area. The potential of the natural area in Batu City is very large to be developed into an agrotourism area without losing local wisdom so that it becomes an opportunity to be managed in order to increase the income of an area, and increase the social standard for the community around agro-tourism. The management of agro-tourism areas can be used wisely, so that the preservation of tourism objects and the environment will have a long-term impact on increasing the income of the surrounding community. Pujon Kidul Tourism Village, which offers nature tourism, education about agriculture, as well as processing its products, and sells processed products. This agro-tourism object is an activity that is fully managed by Village-Owned Enterprises (BUMDes). The various tours offered include vegetable picking tours, fruit picking tours, around agro-tourism using horses, to culinary tours that are provided at the Kafe Sawah (Rice Field Café).

In simple terms, consumption or expenditure are goods and services purchased by tourists in order to fulfill their needs, wants and hopes while living in the tourist areas they visit (Yoeti, 2008). Andrianyta, Ulfah and Hermawan (2016), said that the social impact is related to the economy of the family and the area. while the economic impact is an increase in family welfare. Retnoningsih (2013), said that tourist attraction is very influential on social and economic aspects, when the economic aspects tend to be positive, it is increasing the welfare level of the community in Pandansari Village. Hermawan (2016), stated that there is an increase in job opportunities and doing business for local people around tourism locations. Aida, Boedirochminarni, Nuraini (2017), stated that the Agro-tourism of Belimbing Karangsari in Blitar City has a positive impact on increasing the number of product demands, increasing the amount of production, increasing selling prices, increasing various product innovations. Furthermore, Budi, Muchsin, Sekarsari (2020), stated that the development of citrus-picking agro-tourism destinations had a positive impact on the economic activities of the community, one of which was the opening of new jobs for the surrounding community. Ulfah, Setiawan, Rahmawati (2017), stated that with the existence of an agro tourism area, the benefits can be felt by many parties as well as local residents and the local village government.

So that agro-tourism can continue to develop, the manager needs to know how the characteristics of tourists visiting Pujon Kidul Tourism Village, tourist perceptions of the 
tourism attributes found in the tourist village, and the impact of tourism villages on agribusiness activities of the community around agro-tourism, so that tourists who come can provide additional information and evaluation so that it can be used as a parameter in the management of agro-tourism in the future.

The purpose of this study was to determine the social and economic impact of agro-tourism in Pujon Kidul Village, Batu City.

\section{RESEARCH METHODS}

The location of this study was determined purposively, the sample used in this study was 100 people, of which 30 came from employees who worked at tourist attractions, 30 people came from the surrounding community, and 40 people came from tourists visiting the tourist village. The types of data used in this study are primary data and secondary data. Primary data collection in this study was assisted by using questionnaires, interviews, and observations. While secondary data is obtained from various sources regarding information that is directly related to research such as books, articles, previous research, related agencies such as the Central Statistics Agency (BPS), the local Tourism Board.

\section{RESULTS AND DISCUSSION}

\section{The Economic Impact of Pujon Kidul Tourism Village on the Community}

The economic value and the factors that influence the demand for tourism areamong the important things to know from a tourist area, especially natural tourism. The direct economic impact of regional development includes being able to open new business opportunities for local communities such as restaurants or shops providing souvenirs in the Pujon Kidul tourist village area, increasing community income and the area around tourist objects, providers of playgrounds, lodging provided local residents so that the community around the tourist attraction has increased their standard of living. While the positive influence that occurs indirectly is being able to change the mindset of the community around the tourist attraction to be more open and have a better ability to communicate with tourists.

Based on the field survey, it shows that $56 \%$ or 17 respondents stated that they strongly agreed with the statement that tourist areas gave an increase in family income, $43.3 \%$ or 13 respondents agreed to agree, and $0 \%$ stated that they strongly disagreed that the village tourism provides an increase in people's income. Furthermore, the opinion of the community around the tourist area was $46.6 \%$ or 14 community respondents chose to strongly agree. Then a number of $50 \%$ or 15 community respondents chose to agree, and the remaining $3.33 \%$ or 1 respondent chose not to agree, stating that tourism villages can increase the number of new business opportunities. Furthermore, $70 \%$ or 21 respondents agreed that the development of Pujon Kidul Tourism Village was able to increase the standard of living of the community around the tourist area. As well as $23.3 \%$ or as many as 7 respondents stated that they strongly agreed, and as much as $6.6 \%$ or 2 respondents stated that they did not agree, that the existence of Pujon Kidul Tourism Village was able to improve the standard of living of the community. $53.3 \%$ or 16 respondents who stated strongly agree that Pujon Kidul Tourism Village can increase labor absorption, as well as $43.3 \%$ or as many as 13 community respondents chose to agree, and as much as $3.3 \%$ or 1 person community respondents prefer not to agree, stating that the existence of a tourist village can increase labor absorption. Agustina, Hapsari (2018) said that the positive impacts include expansion of employment, increased income, price fixing, village income, noise, interaction between local communities and tourists, increased intensity of mutual cooperation and agro-tourism waste. Furthermore, Gugushvili, Salukvadze, Salukvadze (2017) stated that the rapid growth of the tourism sector triggers economic growth, but based on other branches of the economy such as agriculture, trade must also be involved in this tourism activity.

\section{The Social Impact of Pujon Kidul Tourism Village on the Community}

Based on the results of the field survey, it shows that as many as $73.33 \%$ or as many as 22 community respondents strongly agree, and $26.66 \%$ or as many as 8 respondents agreed that the development of Pujon Kidul Tourism Village was able to improve good communication and tolerance among others.Furthermore, most of the respondents who strongly agreed, namely $76.7 \%$ or 23 respondents and the remaining $23.3 \%$ or 7 respondents stated that they agreed with the development of the Pujon Kidul Tourism Village being able to increase the pride of the surrounding community in their area. Then a number of $60 \%$ or 18 community respondents chose to disagree, followed by a number of very agreeable answers and $40 \%$ or 12 respondents chose to agree which stated that the Pujon Kidul tourist village improved the performance of local social institutions. A total of $60 \%$ or as many as 18 community respondents chose not to agree, followed by $40 \%$ or 12 respondents chose to agree that the Pujon Kidul tourism village increases the security of the Tourism Village area. Then $66.6 \%$ or 20 community respondents chose to agree, as many as $23.33 \%$ or as many as 7 community respondents chose to disagree, and as many as $10 \%$ or 3 community respondents chose strongly agree that the presence of Pujon Kidul tourism object was able to increase family relations among communities around the tourist area.

Suwantoro (1997) states that tourism must be perceived as a tool or instrument to improve the quality of human relations, the quality of life of local residents and the quality of the environment. Pramusita, Sarinastiti (2017), states that social, economic and cultural aspects can have a positive impact on improving social welfare for the community and for the development of coastal areas.However, in the future, efforts still need to be made to strengthen human resources and strong local institutions. The official shelter of the Trisik 
Beach Youth Organization is also very important to be clarified as the direction for the development of the Trisik Beach area. Mussoa, Francionia (2015), tourism is one of the important sources by creating opportunities in the international market. Dincer, Dincer, Yilmaz (2015), that tourism does not only have economic dimensions but also social, cultural, religious, political, sports, and environmental dimensions.

\section{CONCLUSION}

Based on the results of this study, it can be concluded that, The economic impact on society includes increasing family income, increasing the standard of living of the community, reducing the number of unemployed.The social impact that occurs is increasing public confidence in tourism objects, increasing the performance of social institutions, increasing work ethic, maintaining security and improving family relationships, good communication skills, as well as tolerance among fellow villagers. A very striking change is that the residents around the tourist sites are able to provide good service to tourist visitors.

\section{REFERENCES}

[1] Agustina, C.L., Hapsari, H. 2018. Dampak agrowisata kampung batu terhadap aspek sosial ekonomi dan budaya masyarakat (Studi Kasus di Desa Malakasari, Kecamatan Baleendah, Kabupaten Bandung). AGRICORE:Jurnal Agribisnis dan Sosial Ekonomi Pertanian. 3(1) : 359-426.

[2] Aida, E.N., Boedirochminarni, A., Nuraini, I. 2017. Analisis Peningkatan Ekonomi Masyarakat di Agrowisata Belimbing Karangsari Kota Blitar. Jurnal Ilmu Ekonomi. 1(3):282 - 296.

[3] Andrianyta, H., Ulfah, A., dan Hermawan, H. 2016. Dampak Pemanfaatan Pekarangan dalam Perspektif Sosial dan Ekonomi di
Kalimantan Timur. Prosiding Seminar Nasional Inovasi Teknologi Pertanian 1707 Banjarbaru, 20 Juli 2016.

[4] Budi, S.A., Muchsin, S., Sekarsari, R.W. 2020. Dampak sosial ekonomi pengembangan kawasan destinasi agrowisata petik jeruk. (Studi Kasus di Desa Selorejo Kecamatan Dau Kabupaten Malang). Jurnal Respon Publik. 14(5) : 48-54.

[5] Dincer, F.I. Dincer, M.Z. Yilmaz, S. 2015, "The Economic Contribution of Turkish Tourism Entrepreneurship on the Development of Tourism Movements In Islamic Countries". Procedia - Social and Behavioral Sciences. No. 195, pp. $413-422$. World Conference on Technology, Innovation and Entrepreneurship.

[6] Gugushvili, T. Salukvadze, G. Salukvadze, J. (2017), "Fragmented development: Tourism-driven economic changes in Kazbegi, Georgia”. Annals of Agrarian Science. No. 15, pp. 49-54.

[7] Hermawan, H. 2016. Dampak pengembangan desa wisata nglanggeran terhadap ekonomi masyarakat lokal. Jurnal Pariwisata. 3 (2) : 105-117.

[8] Mussoa, F. Francionia, B. (2015), “Agri-Food Clusters, Wine Tourism and Foreign Markets. The Role of Local Networks for SME's Internationalization". Procedia Economics and Finance. No. 27, pp. 334 - 343. 22nd International Economic Conference - IECS 2015 "Economic Prospects in the Context ofGrowing Global and Regional Interdependencies", IECS 2015.

[9] Pramusita, A., Sarinastiti, E.N. 2017. Aspek Sosial Ekonomi Masyarakat Lokal dalam Pengelolaan Desa Wisata Pantai Trisik, Kulonprogo. Jurnal Pariwisata Terapan. 2(1): 14-25.

[10] Retnoningsih, E. 2013. Dampak pengelolaan wisata agro terhadap kehidupan sosial dan ekonomi masyarakat (Studi Kasus: Kebun Teh Kaligua Desa Pandansari Kab Brebes Jawa Tengah). Jurnal Khasanah Ilmu. 4 (1) : 11-19.

[11] Sudiasa. 2005. Definisi Agrowisata. Tersedia pada: http://blogtopsites.com (10 Maret 2019).

[12] Suwantoro, G. 2004. Dasar-dasar Pariwisata. Yogyakarta: Penerbit Andi.

[13] Ulfah, I.F., Setiawan, A., Rahmawati, A. 2017. Pembangunan Desa Berbasis Potensi Lokal Agrowisata di Desa Bumiaji, Kota Batu, Jawa Timur. Politik Indonesia: Indonesian Political Science Review $2(1): 46-64$.

[14] Yoeti, O. 2008. Ekonomi Pariwisata Introduksi, Informasi, dan Implementasi. Jakarta: PT. Kompas Media Nusantara. 